\title{
HARDNESS OF DENTURE BASE AND HARD CHAIR-SIDE RELINE ACRYLIC RESINS
}

\author{
DUREZA DE RESINAS ACRÍLICAS PARA BASE DE PRÓTESE E \\ REEMBASAMENTO IMEDIATO
}

Andrea AZEVEDO', Ana Lucia MACHADO ${ }^{2}$, Carlos Eduardo VERGANI², Eunice Teresinha GIAMPAOLO ${ }^{2}$, Ana Cláudia PAVARINA ${ }^{3}$

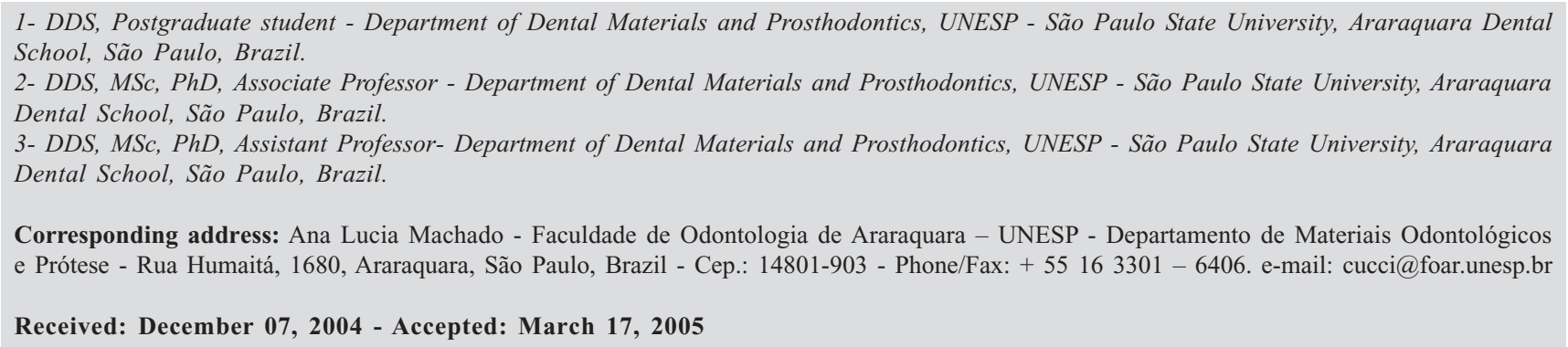

\begin{abstract}
I ntroduction - The hardness of denture base materials may undergo changes due to continued polymerization reaction and water uptake. However, the extent to which these processes affect the hardness of materials is still unclear. Objective - In this study, the degree of conversion of two hard chair-side reline resins (Duraliner II-D and Kooliner-K) and one heat-cured acrylic resin (Lucitone 550-L) was evaluated indirectly by measuring the surface hardness. The effect of immersion in water on this property was also analyzed. Materials and Methods - After processing following the manufacturers' instructions, specimens ( $5 \mathrm{~mm}$ diameter and $2 \mathrm{~mm}$ thickness) were dry stored at room temperature and the Vickers hardness (VHN) was measured with a hardness tester after 0,2, 7,30 and 90 days. Specimens were then immersed in water at $37^{\circ} \mathrm{C}$ and hardness was evaluated after the same time intervals. Five specimens were prepared for each material. Data were analyzed by Kruskal-Wallis test $(\mathrm{P}=.01)$. Results - When dry stored, material L showed an increase in hardness $(\mathrm{P}<.01)$ from 0 -day $(\mathrm{VHN}=23.2)$ to 30-day $(\mathrm{VHN}=27.1)$, after which no significant change was observed. A continuous increase in hardness was observed for material $\mathrm{D}$ from 0-day (VHN=4.6) to 90 -day dry storage ( $\mathrm{VHN}=7.3)$. For material $\mathrm{K}$, an increase in hardness was observed up to 7-day $(\mathrm{VHN}=9.2)$, and then leveled off ( $\mathrm{P}>.01)$. After 2-day water storage, all materials showed a significant reduction in hardness $(\mathrm{P}<.01)$. Conclusion - In general, the hardness of the materials evaluated increased during dry storage and decreased after immersion in water. Uniterms: Denture bases; Acrylic resins; Hardness.
\end{abstract}

\section{RESUMO}

$\Gamma_{\text {n }}$ continuada e absorção de água. Entretanto, a magnitude do efeito de cada um desses processos ainda não foi definida Objetivo - Neste estudo, o grau de conversão de duas resinas autopolimerizáveis para reembasamento (Duraliner II-D and Kooliner-K) e de uma resina termopolimerizável para base de prótese (Lucitone 550-L) foi avaliado, indiretamente, por meio da mensuração da dureza. O efeito da imersão em água sobre essa propriedade também foi analisado. Material e Métodos - Após a polimerização, amostras (diâmetro - $5 \mathrm{~mm}$; espessura - 2 mm) foram armazenadas a seco em temperatura ambiente e a dureza Vickers (VHN) foi mensurada após 0, 2, 7, 30 e 90 dias. As amostras foram, então, imersas em água a $37^{\circ} \mathrm{C}$ e a dureza foi avaliada nos períodos citados. Cinco amostras foram preparadas para cada material. Os resultados foram analisados utilizando-se o teste de Kruskal-Wallis $(\mathrm{P}=.01)$. Resultados - Para o armazenamento a seco, o material $\mathrm{L}$ apresentou aumento significativo na dureza $(\mathrm{P}<.01)$ de $0(\mathrm{VHN}=23.2)$ para 30 dias $(\mathrm{VHN}=27.1)$, após o qual nenhuma diferença significativa foi observada. Aumento contínuo na dureza foi observado para o material D de 0 (VHN=4.6) para 90-dias (VHN=7.3). Para o material K, aumento na dureza foi observado até 7 dias $(\mathrm{VHN}=9.2)$ quando ocorreu a estabilização $(\mathrm{P}>.01)$. Após 2 dias de armazenamento em água, todos os materiais apresentaram redução significativa na dureza $(\mathrm{P}<.01)$. Conclusões - A dureza dos materiais avaliados aumentou durante o armazenamento a seco e diminuiu após a imersão em água.

Unitermos: Bases de próteses; Resinas acrílicas; Dureza. 


\section{INTRODUCTION}

Self-curing hard reline acrylic resins have been used to reestablish close adaptation of the denture bases to their supporting structures, thereby providing retention and stability for the dentures ${ }^{14}$. It has been observed that there is more residual monomer in self-curing acrylic resins than in heat-cured denture base acrylic resins ${ }^{13,21,22}$. This residual monomer is widely recognized as a plasticizer and affects the mechanical properties of polymerized resins ${ }^{2,6,8,13}$. Further polymerization reaction at the free radicals remained within the polymerized resins has been pointed as one important mechanism responsible for continuous improvement of the degree of conversion and decrease of residual monomer level ${ }^{12}$.

Water absorbed into polymerized resins could also act as a plasticizer, thereby altering their mechanical properties ${ }^{15,19,23}$. Considering that during clinical use, the dentures are immersed in saliva and during storage they are soaked in solutions of denture cleansers or water, it is important to assess the influence of water immersion on the mechanical properties of the acrylic resins.

Hardness has been found to be sensitive to the residual monomer content in the polymerized resin ${ }^{8}$. Because hardness is a simple and effective way to assess the degree of conversion of dental polymers ${ }^{18}$, hardness measurements have been successfully used as an indirect method of evaluating polymerization depth of resin-based composite materials ${ }^{7}$ and the degree of conversion of conventional heat-polymerizing and self-curing acrylic resins ${ }^{13}$. In addition, hardness has been used to predict the wear resistance of dental materials ${ }^{4}$. However, to date, little information is available regarding the hardness of the hard chair-side reline materials ${ }^{3}$.

In oral conditions, it is likely that further polymerization reaction $^{12}$ and water uptake ${ }^{1,5}$ mechanisms occur simultaneously. However, to clarify the magnitude of influence of each of these mechanisms on the hardness of denture base materials, the purpose of this study was twofold: 1) to measure and compare the hardness of two hard chair-side reline resins and one heat-cured denture base acrylic resin, in dry state, as an indirect method to estimate their degree of conversion; 2) to evaluate the effect of immersion in water on the hardness of these materials. The hypotheses to be tested were that the mean hardness values were different between materials, were changed with time, and after immersion in water.

\section{MATERIALS AND METHODS}

Two self-curing reline acrylic resins, Duraliner II (Reliance Dental Mfg. Co., Worth, Ill.) and Kooliner (Coe Laboratories, Inc., York, Chicago, Ill.), and a heat-cured denture base acrylic resin, Lucitone 550 (Dentsply International Inc., York, Pa.) were selected for this study. The ingredients of the denture base resin are polymethyl methacrylate, methyl methacrylate and ethylene glycol dimethacrylate. The powder of reline resins consists of poly (ethyl methacrylate). However, the liquid composition of material Kooliner is isobutyl methacrylate, without a cross-linking agent, whereas Duraliner II liquid contains butyl methacrylate and a crosslinking agent.

To facilitate removal of the processed specimens, brass disks ( $5 \mathrm{~mm}$ diameter; $2 \mathrm{~mm}$ thickness) were inserted in hard but flexible silicone rubber (Optosyl Confort and Xantopren; Heraus Kulzer GmbH \& CoKG, Dormagen, Germany) supported by dental stone (Herodent; Vigodent, Bonsucesso, Brazil) within the flasks. The materials were proportioned (Duraliner II - $10 \mathrm{~mL} / 7 \mathrm{~mL}$; Kooliner - $10 \mathrm{~mL} / 4$ $\mathrm{mL}$; Lucitone $550-21 \mathrm{~g} / 10 \mathrm{~mL}$ ), and processed according to the manufacturers' instructions (Duraliner II and Kooliner $12 \mathrm{~min}$ and $10 \mathrm{~min}$ at $37^{\circ} \mathrm{C}$, respectively; Lucitone $550-90$ min at $73^{\circ} \mathrm{C}$ and then $\mathrm{C}$ boiling water for $30 \mathrm{~min}$ ). Five specimens were made for each material and after polymerization and were automatically polished (Metaserv 2000, Buehler UK Ltd, Conventry, Inglaterra) using progressively finer grades (800-1200) of silicon carbide paper (3M, St. Paul, MN, USA). Thereafter, hardness measurements were obtained for all specimens with a Vickers Hardness Tester (Otto Wolpert, Germany) operated under a 30-g load and a 30-second dwell time. When material Duraliner II was tested, the applied load was $10 \mathrm{~g}$, so that the indentation could be properly measured. Eight measurements were made at different points on each specimen, the mean value was recorded, and the Vicker's hardness number (VHN) was then calculated (0 day). Subsequent measurements were made on each specimen after they had been dry stored in lightproof containers with anhydrous sulfate at room temperature $\left(23.0 \pm 1^{\circ} \mathrm{C}\right)$ for $2,7,30$, and 90 days. After the 90 -day dry storage period, the specimens were individually stored in a container with $200 \mathrm{~mL}^{10}$ distilled water at $37^{\circ} \mathrm{C}$ to evaluate the effect of immersion in water on the hardness property. Hardness measurements were made on each specimen after $2,7,30$, and 90 days of water storage.

Because the hardness results did not follow a normal distribution, data were analyzed with the non-parametric Kruskal-Wallis test. The test was used to evaluate separately the significance of hardness differences (1) for each material over time and (2) between the three materials at each measurement time interval. Statistical significance was defined at $1 \%$ level of significance.

\section{RESULTS}

Data of hardness changes during storage of the specimens in dry condition is graphically shown in Figure 1. It can be seen from Figure 1, that a significant $(P<.01)$ increase in hardness was observed for material Duraliner II specimens from 0-day $(\mathrm{VHN}=4.6)$ to 90 -day dry storage period $(\mathrm{VHN}=7.3)$. For material Kooliner, a significant $(P<.01)$ increase in hardness was observed up to 7-day $(\mathrm{VHN}=9.1)$, and then leveled off. Lucitone 550 specimens displayed a significant increase in hardness $(P<.01)$ from 0 -day $(\mathrm{VHN}=23.2)$ to 30 -day $(\mathrm{VHN}=27.1)$, after which no significant 
change $(P>.01)$ was observed. Duraliner II specimens exhibited the lowest hardness mean values in all periods evaluated, whereas Lucitone 550 specimens showed the highest hardness mean values $(P<.01)$.

Figure 2 depicts the hardness changes observed after the specimens had been immersed in water. Statistical analysis revealed that all materials showed a significant reduction in hardness $(P<.01)$ after 2-day water storage. Thereafter, no significant change $(P>.01)$ was noted with the exception of material Kooliner, which showed a slight but significant increase from 30 - to 90 -day $(P<.01)$. Similarly as observed for the dry storage, Lucitone 550 specimens showed the highest hardness mean values in all periods evaluated $(P<.01)$. At 90 -day storage in water, Kooliner specimens hardness mean values were significantly higher than those of Duraliner II specimens $(P<.01)$.

\section{DISCUSSION}

Because of the easy specimen preparation, simplicity of the test method and availability of the equipment, hardness has been widely used as a method of investigating factors that influence the degree of conversion of resins and for characterization of the mechanical quality of a polymer ${ }^{4,7,13,18}$.

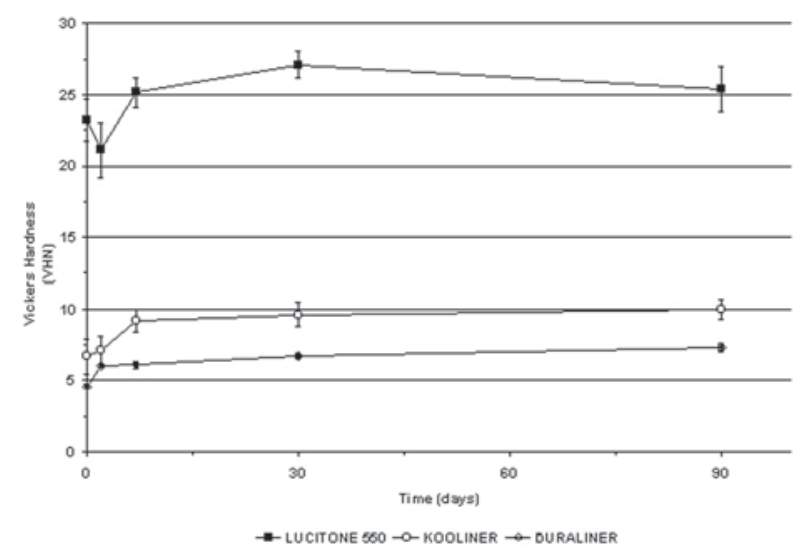

FIGURE 1- Hardness mean values for materials, in dry storage (VHN)

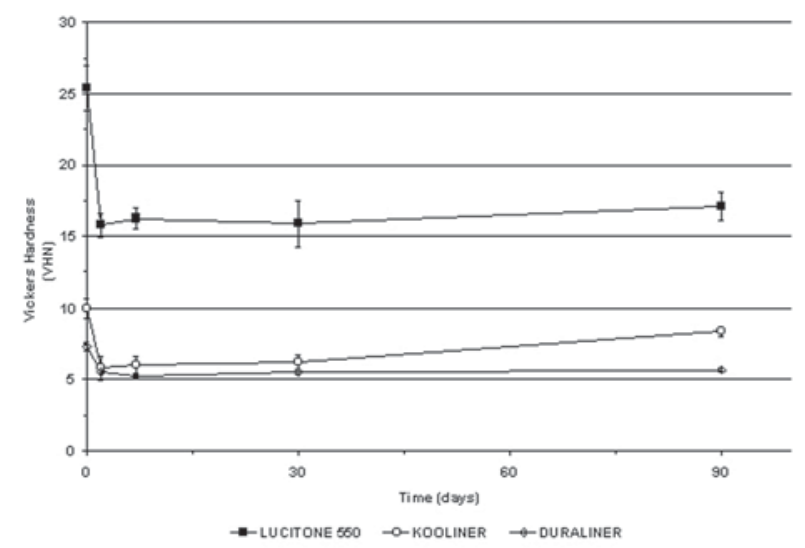

FIGURE 2- Hardness mean values for materials, in water storage (VHN)
Therefore, in this study, the degree of conversion of two hard chair-side reline resins and one denture base resin was indirectly determined by measuring their hardness. Measurements were also made after the specimens were stored in water in order to evaluate the effect of water uptake on hardness property.

When the specimens were stored in dry condition, all materials showed an increase in hardness mean values with time. During the polymerization reaction, the conversion of monomer into polymer is not complete and varying amounts of free or unreacted monomer remain in the polymerized $\operatorname{resin}^{6,9,11,12,13,21,22}$. Residual monomer is a well-known plasticizer and affects the mechanical properties of the acrylic resins ${ }^{2,6,8,13}$. It has been demonstrated that the fall in residual monomer levels that takes place after polymerization is due to further polymerization at the sites of active radicals ${ }^{12}$. Therefore, the increase in hardness observed in present study suggests that monomer to polymer conversion was taking place. Considering that self-curing acrylic resins usually exhibit high residual monomer content ${ }^{13,21,22}$, the increase in hardness for materials Duraliner II and Kooliner was not surprising. Similar results were observed for Lucitone 550 denture base resin, despite the fact that this material was heat-cured. It has been demonstrated that polymerization cycles should include a terminal boil period of at least 1 hour to assure maximum monomer conversion ${ }^{9,22}$. Therefore, because of the 30-minute terminal boil period used for processing Lucitone 550 resin, it is possible that sufficient free radicals still remained in the polymerized specimens to cause a significant increase in degree of conversion during the storage period. This might help explain the observed progressive hardening of the Lucitone 550 specimens.

Duraliner II specimens showed a continuous increase in hardness from 0-day to 90-day dry storage period. Lucitone 550 specimens also showed an increase in hardness up to 30-day, and thereafter no further increase was observed. Material Kooliner showed a different behavior pattern, and the maximum hardness value was attained at 7-day and then remained the same. Lucitone 550 and Duraliner II materials contain cross-linking agents, which result in a more rigid polymer structure ${ }^{16}$. Given that the rate of reaction depends on the segmental mobility in the polymer, the lower rate of hardening of materials Duraliner II and Lucitone 550 could be due to limitations of the mobility of the remaining reactive species imposed by the cross-linked polymeric network ${ }^{22}$.

Consistent with previous research ${ }^{15,19,23}$ the hardness of all materials significantly decreased after water immersion. When acrylic resins are immersed in water, residual monomers release ${ }^{11,13,21}$ and water absorption ${ }^{1,5}$ occur simultaneously. These processes are diffusion controlled and time-dependent ${ }^{1,21}$. It has been demonstrated that both water ${ }^{15,19,23}$ and residual monomer ${ }^{2,6,13}$ molecules act as plasticizers, thus affecting the strength of polymerized resins. As stated by Takahashi et al. ${ }^{20}$ if the constituents that leach out exert a lesser plasticizing effect than water molecules, the strength of polymers should decrease after water immersion. Therefore, the reduction in hardness observed 
for all materials during the first 2 days of water immersion suggests that the water uptake had a more pronounced plasticizing effect than the released residual monomer molecules. In addition, it can be assumed that during the 90day period of dry storage, a certain amount of the residual monomer may have been consumed by further polymerization reaction ${ }^{12}$. However, this should be confirmed by quantitative analysis of residual monomer levels within the denture polymers in the experimental conditions used in the present study. In addition, further studies are needed to investigate the relative proportion of water and residual monomer molecules after water storage.

The present results also demonstrated that once the polymers absorb water and become softened, the structure stabilizes and there was no further reduction in hardness during the total observation time. In fact, at 90-day period, the hardness of Kooliner specimens had returned to their original level. One possible explanation for this finding could be that immersing the material in water at $37^{\circ} \mathrm{C}$ for up to 90 days provided ample time for resin leached not only part of the remaining unreacted monomer but also other soluble constituents that might exert a plasticizing effect.

At any particular time after polymerization, significant differences in hardness were found between the three materials tested, when the specimens were stored in dry condition. The Lucitone 550 heat-cured denture base resin was substantially harder than the Kooliner hard reline resin which, in turn, was harder than the Duraliner II specimens. This finding was in general agreement with other studies, which have shown that the hardness of self-curing acrylic resins is lower than that of heat-cured acrylic resins ${ }^{2,13,23}$. It has been demonstrated that the degree of conversion is usually higher when the polymerization reaction is activated by heat ${ }^{9,22}$. The differences in hardness observed between materials may also be attributed to compositional differences. According to Rawls ${ }^{17}$ the butyl/isobutyl methacrylate molecules increase the backbone separation of the polymer molecules, decreasing the intermolecular interaction. The poly (methyl methacrylate), such as Lucitone 550, is the hardest resin of polymethacrylate esters. As the molecular weight of straight-chain alkyl groups increases, the hardness continues to decrease. Thus, the isobutyl (Kooliner) possesses a lower surface hardness, and the n-butyl (Duraliner II) has an even lower hardness. The lowest hardness values observed for material Duraliner II specimens could be also related to its powder to liquid ratio, since it has been demonstrated that the lower this ratio, the higher the residual monomer left in the polymerized $\operatorname{resin}^{11}$.

As all in vitro studies, specific experimental conditions may affect the clinical relevance of this study. Nevertheless, the considerably low mean values obtained with the reline resins are noteworthy. Assuming that the hardness property indicates how easily the denture base material can be scratched and abraded ${ }^{4}$, it is likely that denture base relined with these materials could be damaged by toothbrushing ${ }^{10}$. Thus, immersion type cleanser probably would be more suitable for denture hygiene. In addition, the results indicated that the hardness property of the materials evaluated may undergo changes resulting from continuing polymerization and water uptake processes. Therefore, the combination of these two mechanisms should influence the hardness of materials used in the present study in oral conditions.

\section{CONCLUSIONS}

Within the limitations of this in vitro study, the following conclusions could be drawn:

1. For each material, the hardness increased with time during the 90-day dry storage period.

2. After dry storage, immersion in water resulted in softening of specimens.

3. Regardless of the experimental conditions, Lucitone 550 specimens showed the highest hardness mean values, whereas Duraliner II specimens exhibited the lowest hardness mean values.

\section{ACKNOWLEDGMENT}

This study was supported by the Brazilian National Council of Research (CNPq - grant \# 520866/00-2)

\section{REFERENCES}

1- Braden M. The absorption of water by acrylic resins and other materials. J Prosthet Dent. 1964;14:307-16.

2- Braun KO, Mello JA, Rached RN, Del Bel Cury AA. Surface texture and some properties of acrylic resins submitted to chemical polishing. J Oral Rehabil. 2003;30:91-8.

3- Buudai S, Ohtani T, Maeda Y, Ishii K, Nokubi T. Hardness of denture reline materials polymerized with different techniques. J Osaka Univ Dent Sch. 1995;35:39-44.

4- Craig RG, Powers JM. Restorative dental materials. St Louis: Mosby; 2002

5- Cucci ALM, Vergani CE, Giampaolo ET, Afonso MCFS. Water sorption, solubility, and bond strength of two autopolymerizing acrylic resins and one heat-polymerizing acrylic resin. J Prosthet Dent. 1998;80:434-8.

6- Dogan A, Bek B, Cevik NN, Usanmaz A. The effect of preparation conditions of acrylic denture base materials on the level of residual monomer, mechanical properties and water absorption. J Dent. $1995 ; 23: 313-8$.

7- Dunn WJ, Bush AC. A comparison of polymerization by lightemitting diode and halogen-based light-curing units. J Am Dent Assoc. $2002 ; 133: 335-41$

8- Frangou MJ, Polyzois GL. Effect of microwave polymerization on indentation creep, recovery and hardness of acrylic denture base materials. Eur J Prosthod Restorative Dent. 1993;1:111-5.

9- Harrison A, Huggett R. Effect of the curing cycle on residual monomer levels of acrylic resin denture base polymers. J Dent. $1992 ; 20: 370-4$. 
10- Harrison Z, Johnson A, Douglas CWI. An in vitro study into the effect of a limited range of denture cleaners on surface hardness and removal of candida albicans from conventional heat-cured acrylic resin denture base material. J Oral Rehabil. 2004;31:460-7.

11- Kedjarune U, Charoenworaluk N, Koontongkaew S. Release of methyl methacrylate from heat-cured and autopolymerized resins: cytotoxicity testing related to residual monomer. Aust Dent J. 1999;44:25-30.

12- Lamb DJ, Ellis B, Priestley D. The effects of process variables on levels of residual monomer in autopolymerizing dental acrylic resin. J Dent. 1983;11:80-8.

13- Lee SY, Lai YL, Hsu TS. Influence of polymerization conditions on monomer elution and microhardness of autopolymerized polymethyl methacrylate resin. Eur J Oral Sci. 2002;110:179-83.

14- Matsumura H, Tanoue N, Kawasaki K, Astuta M. Clinical evaluation of a chemically cured hard denture relining material. J Oral Rehabil. 2001;28: 640-4.

15- Pavarina AC, Vergani CE, Machado AL, Giampaolo ET, Teraoka MT. The effect of disinfectant solutions on the hardness of acrylic resin denture teeth. J Oral Rehabil. 2003;30:749-52.

16- Price CA. The effect of cross-linking agents on the impact resistance of linear poly(methyl methacrylate) denture-base polymer. J Dent Res. 1986;65:987-92.

17- Rawls HR. Dental Polymers. In: Anusavice, K.J, editor. Phillips' Science of Dental Materials. St Louis: W. B. Saunder Company; 2003. p. 143-69.

18- Rueggeberg FA, Craig RG. Correlation of parameters used to estimate monomer conversion in a light-cured composite. J Dent Res. 1988;67:932-7.

19- Stafford GD, Smith DC. Further studies in the properties of denture base polymers. Br Dent J. 1968; 125:529-33.

20- Takahashi Y, Chai J, Kawaguchi M. Equilibrium strengths of denture polymers subjected to long-term water immersion. Int $\mathrm{J}$ Prosthodont. 1999;12:348-52.

21- Vallittu PK, Miettinen V, Alakuijala P. Residual monomer conten and its release into water from denture base materials. Dent Mater. $1995 ; 11: 338-42$.

22- Vallittu PK, Ruyter IE, Buykuilmaz S. Effect of polymerization temperature and time on the residual monomer of denture base polymers. Eur J Oral Sci. 1998;106:588-93.

23- Von Fraunhofer JA, Suchatlampong C. The surface characteristics of denture base polymers. J Dent. 1975;3:105-9. 